\title{
IMPACT OF ORGANIC CHROMIUM ON SOME PRODUCTIVE PERFORMANCES AND PHYSIOLOGICAL RESPONSES OF GROWING BARKI LAMBS
}

\author{
A. E. M. Mahmoud ${ }^{1}$ and A. I. Zanouny ${ }^{2}$ \\ ${ }^{1}$ Animal Production Dept., Faculty of Agriculture, Cairo University, 12613, Giza, Egypt. \\ ${ }^{2}$ Animal and Poultry Production Department, Faculty of Agriculture, Minia University, Minia Egypt.
}

(Received 7/6/2018, accepted $17 / 72018$ )

\section{SUMMARY}

$\mathbf{T}$ This study was conducted to evaluate the effect of chromium methionine on some productive performances and physiological responses of growing Barki lambs. Thirty-three lambs averaged 35.37 $\mathrm{kg}$ body weight; 5 months old were divided into 3 similar groups of 11 animals according to their live weight. The three groups were assigned at random to the three experimental groups as follow: G1: control ration without chromium, G2: control ration with $1.50 \mathrm{mg}$ chromium/head/day, G3: control ration with $3 \mathrm{mg}$ chromium/head/day. The growth trial was conducted for 90 days. Lambs were weighed every two weeks before morning feeding after $15 \mathrm{~h}$ of fasting. Body weight gain was recorded and daily feed intake was calculated. Dry matter (DM), total digestible nutrients (TDN) and digestible crude protein (DCP) intake were calculated. Feed efficiency ratio was calculated. Results indicated that, either G2: $1.50 \mathrm{mg} / \mathrm{head} / \mathrm{day}$ or $\mathrm{G} 3: 3 \mathrm{mg} / \mathrm{head} / \mathrm{day} \mathrm{Cr}$ supplementation had no effects on the digestibility of DM, OM, CP, EE and DCP, but G3 (3 mg /head/day). But had significant $(\mathrm{P}<0.05)$ increase on digestibility of $\mathrm{CF}$, NFE and TDN compared with G2 and control group. At the same time $\mathrm{Cr}$ supplementation did not affect on globulin, creatinine, ALT and AST in blood plasma. Furthermore, no effect on urea. At the same time G3 (3 mg /head/day) Cr supplementation led to increase protein, albumin and blood glucose compared with G2 and control group. In addition, $\mathrm{Cr}$ supplementation had no effects on rumen $\mathrm{pH}$, Total volatile fatty acids (TVFA's) and ammonia concentrations at zero time and at 4 hours post feeding. At the same time G2 (1.50 mg /head/day) or G3 (3 mg Cr/head/day) had significant $(\mathrm{P}<0.05)$ increase total weight gain and average daily gain. Thus, Cr supplementation in G2 and G3 improved feed efficiency. From the present results it can be concluded that supplementation of $\mathrm{Cr}$ in organic form led to positive effect on deferent performances as a result of improving physiological responses.

Keywords: chromium methionine, blood performance, Physiological responses, Barki lambs.

\section{INTRODUCTION}

Trace minerals required by farm animals at low doses, but it have an important role in the metabolic process and prevents many health problems. Chromium $(\mathrm{Cr})$ as trace mineral required as an essential nutrient. However, its daily requirements are not established yet, but it seems that they increase under certain stress conditions like exercise, transport and sickness. (Anderson, 1987 and NRC, 2007).

Functions and effects of $\mathrm{Cr}$ involve an increment in cellular sensibility to insulin, which influences on the metabolism of carbohydrate, lipids and protein (Mertz, 1993) and on the sensitivity of cells to insulin and glucose metabolism (NRC, 1989 and NRC, 2007). In addition, chromium is necessary in protein synthesis and corporal growth and also, improves productivity due to a better energy metabolism (Jacques and Steward, 1999). However, the magnitude of the metabolic response of $\mathrm{Cr}$ apparently depends on the chemical form. Organic forms are more effective than inorganic ones (Page et al., 1993), since the level of absorption of these is very low from 0.4 to 3.0\% (Anderson et al., 1997). Lindemann et al. (1995) suggested that the use of organic sources of $\mathrm{Cr}$ as an alternative for their increased biological availability to be more soluble in all the digestive tract and reduce the risk of negative interactions with other minerals. According to that $\mathrm{Cr}$ considered as a metabolic manipulator with the potential to improve growth rate, enhance feed efficiency and profitability of livestock production (Dikeman, 2007). 
The predominant physiological role of $\mathrm{Cr}$ is as an integral component of the organo-metallic molecular complex called glucose tolerance factor (GTF), which facilitates the cellular binding and actions of insulin and promotes the utilization of glucose and other metabolites by cells (Vinson and Hsiao, 1985). Glucose tolerance factor is the most biologically active form of $\mathrm{Cr}$, but is usually low in plant-origin diets. However, organic $\mathrm{Cr}$ such as $\mathrm{Cr}$ picolinate ( $\mathrm{CrPic}$ ), $\mathrm{Cr}$ nicotinate (CrNic), amino acid-chelated $\mathrm{Cr}$, and high-Cr yeast has demonstrated

Sheep studies have focused on evaluating the effect of $\mathrm{Cr}$ in nutrients metabolism (Da Rocha et al., 2013 and Zhou et al., 2013), immunological status and carcass characteristics (Domínguez-Vara et al., 2009 and Yan et al., 2010). Therefore, the objective of this study was to evaluate the effects of different levels of $\mathrm{Cr}$ supplementation in organic form on some performances and physiological responses in lambs.

\section{MATERIALS AND METHODS}

\section{Experimental design:}

A growth trial was conducted for 90 days. Thirty three Barki lambs averaged $35.37 \mathrm{~kg}$ body weight; 5 months old were divided into 3 similar groups of 11 animals according to their live weight. The three groups were assigned at random to the three experimental groups as follow: G1: control ration without chromium, G2: control ration with $1.50 \mathrm{mg}$ chromium/head/day, G3: control ration with $3 \mathrm{mg}$ chromium/head/day. Chromium used in this experiment was in organic form (Availa ${ }^{\circledR} \mathrm{Cr} 1000$ ) chromium methionine from ZINPRO Company. The formulation and chemical composition of basal ration is presented in Table (I).

Table (1): Formulation and chemical composition of basal ration.

\begin{tabular}{|c|c|c|c|}
\hline Ingredient & $\%$ & Chemical composition & $\%$ \\
\hline Alfaalfa hay $(16 \% \mathrm{CP})$ & 40 & Dry matter $(\mathrm{DM})$ & 93.15 \\
\hline Yellow corn & 36 & Organic matter (OM) & 89.59 \\
\hline Soybean meal (44\%CP) & 3.6 & Ash & 10.41 \\
\hline Sunflower meal( $36 \%$ CP) & 6 & Crude protein $(\mathrm{CP})$ & 15.80 \\
\hline Wheat bran & 12 & Crude fiber $(\mathrm{CF})$ & 14.39 \\
\hline Limestone & 1.5 & Nitrogen free extract (NFE) & 56.30 \\
\hline Salt & 0.66 & Ether extract $(\mathrm{EE})$ & 3.10 \\
\hline$*$ Premix & 0.18 & Acid detergent fiber (ADF) & 42.20 \\
\hline Anti-toxin & 0.06 & Neutral detergent fiber (NDF) & 28.71 \\
\hline
\end{tabular}

The growing lambs were fed concentrate feed mixture and clover hay twice daily to cover their total requirements of sheep according to NRC (1985), animals were fed in groups. Orts were collected just before offering the next day feed. Fresh water was allowed all the day round time. Lambs were weighed every 15 days after $15 \mathrm{~h}$ of fasting before morning feeding. Body weight gain was recorded and daily feed intake was calculated. Dry matter (DM), total digestible nutrients (TDN) and digestible crude protein (DCP) intake were calculated. The feed efficiency ratio was calculated as follow daily gain $\mathrm{g} /$ daily feed intake as DM. At 90 day from beginning 5 animals from each group were used in digestibility trials to evaluate the experimental rations for TDN and DCP, according to Van Keulen and Young (1977).

\section{Sampling and analytical procedures:}

\section{Chemical analyses:}


Dried feeds, orts, feces samples were ground through a wiley mill using a $1 \mathrm{~mm}$ screen. Samples were analyzed according to AOAC (2000), fiber fractionations (NDF and ADF) were completed according to Van Soest et al. (1991). Nitrogen free extract was calculated by difference.

\section{Rumen liquor sampling:}

Just before morning feeding rumen liquor samples were taken (four hours post feeding). Samples of rumen liquor were strained through two layers of cheesecloth and its $\mathrm{pH}$ was immediately measured after collection. The $\mathrm{pH}$ value of rumen liquor samples was determined using $\mathrm{pH}$ meter. Quantitative analysis of Total volatile fatty acid and ammonia concentration were carried out according to Szumacher-Strabel and Potkanski (2002).

\section{Blood parameters:}

Blood samples were taken from 5 animals at the end of the digestibility trials. Blood plasma parameters were analyzed using commercial kits obtained from Stanbio Laboratory, Boerne, Texas, USA. Total protein and creatinine were determined according to Tietz (1986) and Tietz and Saunders (1990), respectively. Albumin was determined according to Doumas et al. (1971). Blood plasma urea was determined according to Patton and Grouch (1977). Alanin amino transferase (ALT) and aspartate amino transfearse (AST) activities were colorimetrically determined according to Young (1997). Glucose was executed according to Trinder (1969).

\section{Statistical analysis:}

Data were analyzed using the general linear model procedure of SAS (2001). One way ANOVA procedure used to analyze data according to the next model; $Y_{i j}=\mu+T_{i j}+e_{i j}$, were: $\mu$ is the overall mean of $Y_{i j} ; T_{i j}$ is the treatment effect; the $e_{i j}$ is the experimental error. Differences among means were separated according to Duncan New Multiple Range Test (Duncan, 1955).

\section{RESULTS AND DISCUSSION}

\section{Digestion coefficients and nutritive values:}

Results in Table (2) indicated that, either G2 $(1.50 \mathrm{mg} / \mathrm{head} / \mathrm{day})$ or G3 (3 $\mathrm{mg} / \mathrm{head} / \mathrm{day}) \mathrm{Cr}$ supplementation had no effects on the digestibility of DM, OM, CP , EE and DCP, but G3 had significant $(\mathrm{P}<0.05)$ increase in digestibility of $\mathrm{CF}, \mathrm{NFE}$ and TDN compared with $\mathrm{G} 2$ and control group.

Table (2): Digestion coefficients and nutritive values of the experimental groups.

\begin{tabular}{lllll}
\hline Item & \multicolumn{3}{c}{ Treatments } & \multirow{2}{*}{ \pm SE } \\
\hline DM & G1 & G2 & G3 & 0.38 \\
OM & 83.25 & 83.49 & 83.84 & 0.37 \\
CP & 84.39 & 85.13 & 84.93 & 0.53 \\
EE & 78.92 & 80.82 & 78.93 & 0.81 \\
CF & 84.43 & 84.08 & 82.05 & 0.53 \\
NFE & $74.50^{\mathrm{b}}$ & $75.51^{\mathrm{ab}}$ & $77.28^{\mathrm{a}}$ & 0.95 \\
Nutritive values \% & $69.45^{\mathrm{b}}$ & $71.73^{\mathrm{b}}$ & $75.12^{\mathrm{a}}$ & \\
TDN & & & & 0.52 \\
DCP & $72.93^{\mathrm{b}}$ & $73.30^{\mathrm{ab}}$ & $74.24^{\mathrm{a}}$ & 0.90 \\
\hline
\end{tabular}

a, ${ }^{5}$ :Means in the same row with different superscript are significantly differ $(P<0.05)$. G1: Control group without chromium, G2: Control ration with 1.5mg chromium/head/day, G3: Control ration with $3 \mathrm{mg}$ chromium/head/day, TDN: Total digestible nutrients and DCP: Digestible crude protein.

\section{Rumen parameters:}

Results in Table (3) illustrated that, G2 (1.50 mg /head/day) and G3 (3 mg /head/day) $\mathrm{Cr}$ supplementation had no effects on rumen $\mathrm{pH}$, TVFA and ammonia concentrations at zero time and at 4 
hours post feeding. These results are agreement with Besong et al. (2001) they found that the effects of supplemental $\mathrm{Cr} 0.8 \mathrm{mg} / \mathrm{kg}$ of $\mathrm{Cr}$ as chromium picolinate had no effects on rumen TVFA's concentrations at 12 and 24 hours for Holstein steers.

Table (3): Rumen parameters of the experimental groups.

\begin{tabular}{lcccc}
\hline Item & \multicolumn{3}{c}{ Treatments } & GSE \\
\hline Rumen pH & G1 & G2 & G3 & \\
At zero time & & & & \\
At 4 hours post feeding & 6.78 & 6.81 & 6.92 & 0.09 \\
Mean & 6.22 & 6.25 & 6.35 & 0.08 \\
Rumen Ammonia (mg/100 ml) & 6.50 & 6.53 & 6.64 & 0.08 \\
At zero time & & & \\
At 4 hours post feeding & 10.29 & 9.94 & 9.53 & 0.26 \\
Mean & 11.21 & 11.69 & 12.10 & 0.24 \\
Total volatile fatty acids (meq/100 ml) & 11.19 & 10.82 & 10.73 & 0.22 \\
At zero time & & & & 0.08 \\
At 4 hours post feeding & 6.94 & 6.78 & 6.94 & 0.10 \\
Mean & 8.51 & 8.77 & 8.83 & 0.09 \\
\hline
\end{tabular}

G1: Control group without chromium, G2: Control ration with 1.5mg chromium/head/day, G3: Control ration with $3 \mathrm{mg}$ chromium/head/day.

\section{Blood parameters:}

Data in Table (4) illustrated that Cr supplementation led to no significant effect on globulin, creatinine, ALT and AST in blood plasma. Furthermore, no effect on urea and total protein. Similar results were reported by Sung et al. (2015) in steer.

Also, similar results were reported by Kitchalong et al. (1995) in lambs. At the same time G3 (3 mg /head/day Cr supplementation) had significant $(\mathrm{P}<0.05)$ increase on albumin and blood glucose compared with G2 and control group. Also, the present results are agreement with Domínguez-Vara et al. (2009). They fund that using $0.25 \mathrm{mg} \mathrm{Cr} / \mathrm{d}$ increase plasma glucose concentrations as the Cr-yeast supplemented in lambs ration. Cr-yeast might have acted indirectly on glucose metabolism as results effect on insulin secretion. Chromium has potentiated insulin action by enhancing its binding to target cell receptors and also by improving its post-receptor signaling. Insulin has increased protein synthesis, efficiency of amino acid transport, reduced protein degradation rate and increased carbohydrate and lipid utilization. The present results indicated that, there are increases in the total protein $(\mathrm{P}>0.05)$ and albumin $(\mathrm{P}<0.05)$ in $\mathrm{G} 2$ and $\mathrm{G} 3$ as a result of supplementation of $\mathrm{Cr}$ in comparison with control group. The increase in previous parameters may be due to the positive effect of Cr supplementation in insulin secretion. Debski et al. (2004) reported that, supplementation of $\mathrm{Cr}$-yeast led to positive effect of protein synthesis.

Although the physiological mechanism by which insulin function is purportedly enhanced by organic chelates of $\mathrm{Cr}$ is unknown, it may be due to the direct action of this trace element on insulin-sensitive tissues in response to changes in circulating insulin and glucose levels. For instance, in human and rat tissues, $\mathrm{Cr}$ disappearance from the blood and uptake by insulin-sensitive tissues is enhanced by insulin and glucose (Morris et al., 1993).

Table (4): Blood parameters of the experimental groups.

\begin{tabular}{lllll}
\hline Item & \multicolumn{4}{c}{ Treatments } \\
\hline & G1 & G2 & G3 \\
\cline { 2 - 4 }
\end{tabular}




\begin{tabular}{lllll}
\hline Total proteins, g/dl & 5.95 & 6.27 & 6.52 & 0.13 \\
Albumin, g/dl & $2.80^{\mathrm{b}}$ & $2.80^{\mathrm{b}}$ & $3.10^{\mathrm{a}}$ & 0.06 \\
Globulin, g/dl & 3.15 & 3.47 & 3.42 & 0.13 \\
Urea, mg/dl & 37.00 & 35.75 & 38.00 & 0.70 \\
Creatinine, mg/dl & 1.05 & 1.12 & 1.05 & 0.03 \\
ALT, IU/L & 43.50 & 45.50 & 47.00 & 0.84 \\
AST, IU/L & 46.50 & 44.75 & 44.75 & 0.62 \\
Glucose, mg/dl & $63.00^{\mathrm{b}}$ & $71.00^{\mathrm{ab}}$ & $76.75^{\mathrm{a}}$ & 2.45 \\
\hline
\end{tabular}

${ }^{a, b}$ :Means in the same row with different superscript are significantly differ $(P<0.05)$, G1: Control group without chromium, G2: Control ration with 1.5mg chromium/head/day, G3: Control ration with $3 \mathrm{mg}$ chromium/head/day.

\section{Growth performance and feed efficiency}

Results in Table (5) showed that, G2 (1.50 mg /head/day) or G3 (3 mg /head/day) Cr supplementation had significant $(\mathrm{P}<0.05)$ increase in total weight gain and average daily gain. Generally, Cr supplementation in G2 and G3 improved feed efficiency.

Several authors suggest that chromium supplementation improve the growth performance of lambs. Domínguez-Vara et al. (2009) used 0.0, 0.25 and $0.35 \mathrm{mg} \mathrm{kg}-1$ dry matter of organic Cr in Rambouillet sheep, they found that supplementation of Cr led to positive effect on dry matter intake and feed efficiency and linear increment in final live weight, total gain weight and daily weight gain as doses of $\mathrm{Cr}$ increased. Likewise, Estrada et al. (2014) to assess different levels of Cr-enriched yeast (1, 2 or $3 \mathrm{~g} \mathrm{~d}-1)$ increased the growth of sheep. Also, Chang and Mowat (1992) and Moonsie- Shageer and Mowat (1993) found that chromium-nicotinic acid complex supplementation in ration of calves increased average daily gain and improved feed intake and feed efficacy. In addition Moonsie-Shageer and Mowat (1993) found that, chromium supplementation of stressed calves also has improved or at least tended to improve gain and feed efficiency.

Table (5): Growth performance and feed efficiency of the experimental groups.

\begin{tabular}{lllll}
\hline Item & \multicolumn{3}{c}{ Treatment } & \pm SE \\
\hline Initial body weight, $\mathrm{kg}$ & $\mathrm{G} 1$ & $\mathrm{G} 2$ & $\mathrm{G} 3$ & 2.70 \\
Final body weight, $\mathrm{kg}$ & 35.33 & 35.42 & 35.37 & 4.38 \\
Total weight gain, $\mathrm{kg}$ & 49.82 & 51.44 & 52.92 & 2.96 \\
Average daily gain, g & $14.94^{\mathrm{b}}$ & $16.02^{\mathrm{ab}}$ & $17.55^{\mathrm{a}}$ & 5.61 \\
Feed efficiency & $166^{\mathrm{b}}$ & $178^{\mathrm{ab}}$ & $195^{\mathrm{a}}$ & --- \\
Average Dry matter Intake (g/head/day) & 107 & 113 & 121 & --- \\
Improvement in feed efficiency & 1545 & 1576 & 1602 & --- \\
\hline a, b: Means in the same row with different superscript are significantly differ (P<0.05), G1: control group without \\
chromium, G2: control ration with 1.5mg chromium/head/day, G3: control ration with 3mg chromium/head/day, FCR: \\
feed conversion ratio.
\end{tabular}

\section{CONCLUSION}

From the previous result it can be concluded that supplementation of $\mathrm{Cr}$ in organic form led to positive effect on different productive performances as a result of improving physiological responses.

\section{REFERENCES}


Anderson R A. (1987). Chromium. In Mertz W, ed., Trace Elements in Human and Animal Nutrition. $5^{\text {th }}$ ed. Academic Press, San Diego, CA. pp. 225-244.

Anderson, R.A.; N.A.Bryden; C.M. Evock-Clover and N.C. Steele (1997). Beneficial effects of chromium on glucose and lipid variables in control and somatotropin-treated pigs are associated with increased tissue chromium and altered tissue copper, iron, and zinc. J. Anim. Sci., 75: 657-661.

AOAC (2000). Association of Official Analytical Chemists. Official Methods of Analysis, Washington, USA.

Besong S; J. A Jackson; D. S. Trammell and V. Akay (2001). Influence of supplemental chromium on concentrations of liver triglyceride, blood metabolites and rumen VFA profile in steers fed a moderately high fat diet. Journal of Dairy Science 84: 1679-1685.

Chang, X and D. N. Mowat (1992). Supplemental chromium for stresses and growing feeder calves. Journal of Animal Science. 70: 559-565.

Da Rocha, X. J. F.; A.A.Rodrigues; N.A.Gonçalves; F. E. M.Moraes; K. G.Vilmar; A. C.de Vargas; F. L. D'Avila; C. M. da Silva and L. M. L. do Rego (2013). Metabolism, feed intake, and digestibility of lambs supplemented with organic chromium. Biological Trace Element Research. 156: 130-133.

Debski, B.; W. Zalewski; M.A.Gralak and T. Kosla (2004). Chromium-yeast supplementation of chicken broilers in an industrial farming system. J. Trace Elem. Med. Biol., 18: 47-51.

Dikeman M E. (2007). Effects of metabolic modifiers on carcass traits and meat quality. Meat Science. 77: $121-135$.

Domínguez-Vara, I. A; S. S. González-Muñoz; J. M.Pinos-Rodríguez; J. L.Bórquez-Gastelum; R. BárcenaGama; G.Mendoza- Martínez; L. E. Zapata and L. L. Landois-Palencia (2009). Effects of feeding selenium-yeast and chromium-yeast to finishing lambs on growth, carcass characteristics, and blood hormones and metabolites. Animal Feed Science and Technology. 152: 42-49.

Doumas, B.T.; W.A.Watson and H.G. Biggs (1971). Clin. Chem. Acta. 31: 87-96,

Duncan, D. B. (1955). Multiple range and multiple F- test. Biometrics, 11:1.

Estrada, A. A; Y. S. Valdés; M. O. Carrillo; P. B. I. Castro; A. Barreras; S. M. A. López; A. Plasencia; R. H. Dávila; F. G. Rios and R. A. Zinn. (2014). Effects of feeding different levels of chromium enriched live yeast in hairy lambs fed a corn-based diet: Effects on growth performance, dietary energetic, carcass traits and visceral organ mass. Animal Production Science. 53:308-315.

Jacques, K. and S. Steward (1999). Chromium essential roles in metabolism responses in practical diets. Feed Compounder. 12: 12-13.

Lindemann, M. D; C. M. Wood; A. F. Harper; E. T. Kornegay and R .A. Anderson. (1995). Dietary chromium picolinate additions improve gain:feed and carcass characteristics in growingfinishing pigs and increase litter size in reproducing sows. Journal of Animal Science. 73: 457-465.

Mertz W. (1993). Chromium in human nutrition: A review. Journal of Nutrition. 123: 626-633.

Morris, B.W.; T.A. Gray and S. MacNeil (1993). Glucose-dependent uptake of chromium in human and rat insulin-sensitive tissues. Clin. Sci., 84: 477-482.

Moonsie-Shageer, S. and D.N. Mowat (1993). Effect of level of supplemental chromium on performance, serum constituents, and immune status of stressed feeder calves. Journal of Animal Science. 71: 232238.

NRC (1985) Nutrient requirements of sheep. $6^{\text {th }}$ ed. National Academy Press, Washington, D.C., USA.

NRC (1989). Recommended dietary allowance, $10^{\text {th }}$ edition. National Academy Press. Washington, D.C., USA.

NRC. (2007). Nutriment Requirements of Small Ruminants: Sheep, Goats, Cervids, and New World Camelids. National Academy Press, Washington, D.C., USA. p. 362.

SAS (2004). SAS/STAT 9.1 User's Guide: Statistics, SAS Institute Inc., Cary, N.C., USA. 
Sung, K. I. J;Ghassemi Nejad, S. M; Hong, S. J; Ohh, B. H;Lee, J. L;Peng, D. H. Ji and B. W. Kim (2015). Effects of forage level and chromium-methionine chelate supplementation on performance, carcass characteristics and blood metabolites in Korean native (Hanwoo) steers. J. Anim. Sci. Technol., 57:1420.

Szumacher-Strabel, M. and A. Potkanski (2002). The influence of supplemental fat on rumen volatile fatty acid profile, ammonia and $\mathrm{pH}$ levels in sheep fed a standard diet. Agricultural University, Poznan (Poland). Dept. of Animal Nutrition and Feed Management.

Tietz, N. W. (1986). Textbook of clinical chemistry. W. B. Saunders, Philadelphia, p. 1281-1271.

Tietz, N. W. and W. B. Saunders (1990).Clinical guide to laboratory Philadelphia, 26-29.

Trindr P. (1969) Ann. Clin. Biochem., 6: 24.

Ohh, S. J. and J. Y. Lee (2005). Dietary chromium-methionine chelate supplementation and animal performance. Asian Australas. J. Anim. Sci., 18: 898-907.

Page, T. G; Southern, L. L; Ward, T. L and Jr D L Thompson (1993). Effect of chromium picolinate on growth, serum and carcass traits of growing-finishing pigs. Journal Animal Science. 71: 656-662.

Patton, C.J. and S.R. Crouch (1977). Spectrophotometric and kinetics investigation of the Berthelot reaction for the determination of ammonia. Analytical Chemistry. 49: 464-469.

Van Keulen, J. and B. A. Young (1977). Evaluation of acid insoluble ash as a natural marker in ruminant digestibility studies. J. Anim. Sci., 47, 2: 282-287.

Van Soest P.J.; J.B. Robertson and Lewis B.A. (1991): Methods for dietary fiber, neutral detergent fiber and nonstarch polysaccharides in relation to animal nutrition. J. Dairy Sci., 74: 3583-3597.

Vinson, J. A. and K.-H. Hsiao (1985). Comparative effect of various forms of chromium on serum glucose: An assay for biologically active chromium. Nutr. Rep. Int., 32:1-7.

Yan, X.; F. Li D. Zhang; X.Zhu and Z. Jia (2010). Effects of chromium on energy metabolism in lambs fed with different protein levels. Asian-Australasian Journal of Animal Science. 23: 205-212.

Young, K. S. (1997). What makes online usage stimulating? Potential explanations for pathological Internet use. Symposia paper presented at the $105^{\mathrm{th}}$ Annual Meeting of the American Psychological Association, Chicago.

Zhou, B.; H.Wang; G. Luo; R. Niu and J. Wang (2013). Effect of dietary yeast chromium and L-carnitine on lipid metabolism sheep. Biological Trace Element Research. 155: 221-227. 
تأثير الكروميوم العضوي علي بعض الخصائص الانتاجية والاستجابات الفسيولوجية علي الحملان البرقي النامية

$$
\begin{aligned}
& \text { عادل عيد محم محمود1' و عبدالرحمن ابراهيم زنونى } 2 \\
& 1 \text { قسم الانتاج الحيواني ـ كلية الزراعة ـ جامعة القاهرة- الجيزة - مصر. } \\
& \text { 2 قسم الإنتاج الحيوانس والد/جنى_ كلية/لنزراعة - جامعة المنيا - الدنيا - مصر. }
\end{aligned}
$$

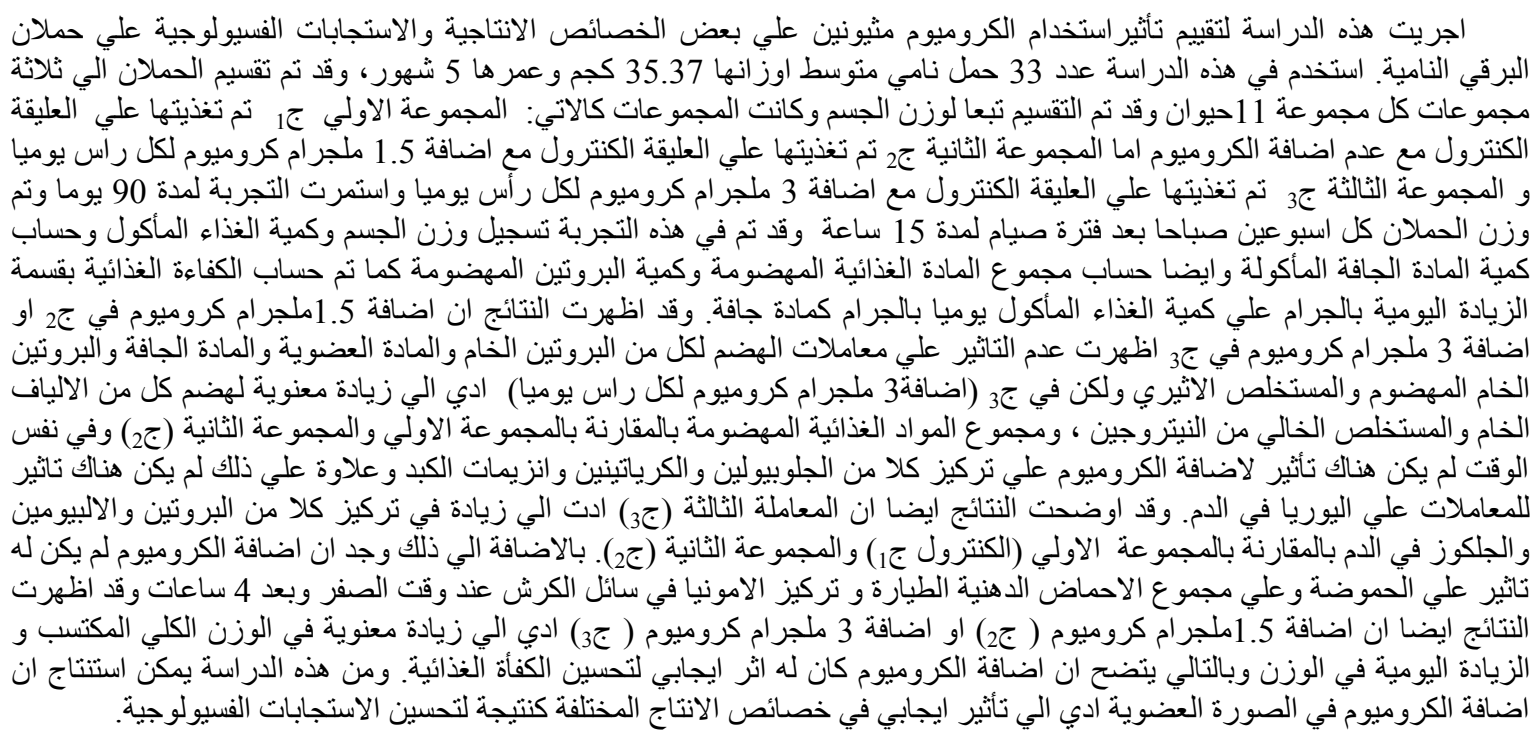

